\title{
HOUSING-LEGISLATIVE PROPOSALS
}

\author{
PhILIP H. HILL*
}

"The fundamental purpose of Government is to protect the health, safety and general welfare of the public. All its complicated activities have that simple end in view. ... Whenever there arises, in the State, a condition of affairs holding a substantial menace to the public health, safety or general welfare, it becomes the duty of the Government to apply whatever power is necessary and appropriate to check it." There has been increasing recognition by the Congress that the housing shortage which has been accumulating steadily over the past two decades represents an area of such public concern as to require that various forms of governmental assistance shall be made available to assure the production of good housing in adequate volume and at prices or rents which will meet the needs of all income groups.

Today, in the midst of innumerable shortages resulting from the war, we tend to think of the current emergency shortage of housing as just another war-born shortage. However, unlike other current shortages which must be overcome in the course of conversion from war production to the production of the kinds of goods and services required to meet the needs of a nation again at peace, the current critical housing shortage is not, basically, a temporary or war-born shortage. As was stated in an editorial in Life Magazine, "By now it is clear that the housing shortage is not a temporary or war-born dislocation. ... O Our homeless veterans are merely the most dramatic victims of a shortage whose ultimate victims are the American family and the American standard of living." We cannot get at the roots of the current shortage of housing for veterans unless we place it in the context of the cumulative housing shortage dating back to the beginning of the decline in home building after 1925 .

Few industries have shown such wide fluctuations in production from year to year as the housing industry, which has varied from an all-time high of more than 900,000 homes started in 1925 to a low of about 90,000 homes started in 1932. Up to the present time we have never been able to continue a sustained high annual volume of house construction. With few exceptions, we have never built enough housing each year to keep pace with the annual net addition in the number of newly

- LL.B., 1926, West Virginia University. Member of the West Virginia Bar. City Solicitor of Charleston, West Virginia, 1935-1942. Special Legal Consultant on Housing for National Institute of Municipal Law Officers. Served in U. S. Naval Reserve $1942-1946$ as an officer on U. S. S. Lexington and as Flag Secretary to Rear Admiral Felix B. Stump, USN, in the Pacific; released from Navy in 1945, Lt. Commander.

${ }^{1} \mathrm{New}$ York City Housing Authority v. Muller, 270 N. Y. 333 , I N. E. (2d) I53 (1936). 
formed families. We have never been able to follow a consistent practice of replacing any significant amount of the housing which is no longer satisfactory because most of our past housing production has to be kept in use.

It is true, of course, that after the cessation of hostilities in World War II building materials were in extremely short supply. This shortage was sharply accentuated by an overwhelming demand for all types of building materials, due, in large part, to the normal peacetime demands which necessarily were deferred during the war period. The building materials shortage had to be solved first if we were to get any substantial volume of housing built. The need for rapidly increasing the production of building materials was finally translated into a legislative proposal in the form of the bill (H.R. 476I, 79th Congress) introduced by Congressman Patman of Texas on November 20, 1945, and subsequently enacted as the Veterans' Emergency Housing Act of 1946 , on May 22, I946.2

However, so far as the attainment of a sustained high annual volume of residential construction is concerned, the shortage of building materials is not the basic problem. Before the war, when there was no shortage of building materials, we had a low annual volume of house construction and a housing shortage. Basically, our housing difficulties result from the fact that, even under prewar conditions, the housing produced through the normal operations of private enterprise cost too much. This has been clearly recognized by many outstanding members of the Congress. The Honorable Robert A. Taft, senior Senator from Ohio, has stated this problem very clearly:

"Mr. President, the basic difficulty in dealing with the housing problem relates to the cost of housing in relation to the income of the people in the United States. We cannot build new houses in the United States for more than the upper half of the income groups in the population....

"There is a greater lack of new rental housing than there is of housing to buy, because very few people are willing to invest their money in rental housing. It has not been very successful. The fact that they must obtain rents which half the people cannot pay means that they are rather unwilling to invest in new rental housing, particularly at present high costs.

"It is claimed that private enterprise, without any aid from the Government, can solve the problem. I think that is contradicted by the facts and the figures. Private enterprise cannot solve the problem, because it cannot build for half the population. It cannot be done."3

On rare occasions this basic difficulty has been recognized by the house building industry itself. The June, 1946, edition of 'The Bildor, a publication of the Builders' Association of Metropolitan Detroit, stated in an editorial, "There is a limit to the number of houses which can be sold at from $\$ 9,000$ to $\$ 15,000$, even in this exuberant housing market; even today the number of families having savings or incomes permitting purchases at these prices are comparatively small compared to the great mass

6o Stat. - (1946), 50 U. S. C. A. App. (supp. pamphlet, 1946) \$1821.

- Cong. Rec., April II, 1946, at 3580, 3581. 
of potential home owners. The $\$ 9,000$ to $\$ 15,000$ class represent only the cream on the top of the bottle. Some time that cream will be all skimmed off."

The legislative proposal addressed to this most important phase of the housing problem, both current and long-term, is the General Housing Bill. This bill was introduced on November I4, I945, under the joint sponsorship of the Honorable Robert F. Wagner, senior Senator from New York, the Honorable Allen J. Ellender, senior Senator from Louisiana, and the Honorable Robert A. Taft, senior Senator from Ohio.

It is unfortunate that, traditionally, legislation which deals with social or economic problems immediately invites attack by a host of groups who categorically regard all such legislation as presumptively unsound and unnecessary. The WagnerEllender-Taft General Housing Bill has received perhaps more than its share of comment from groups who have not been constrained to rational consideration of its merits. The President of the National Association of Home Builders characterized as "extremely factual" the following evaluation of the Bill contained in a Washington News Letter of that organization:

\section{"WASHINGTON SIDE SHOW}

"HUREE . . . HUREE . . . HUREE! Step right this way folks and see the wONDER BILL of THE AGE! ... Don't push-don't shove-there's room for one, there's room for all, there's room for everyonel ... Step up and see the GREATEST of all Housing BILLs-it's Democratic-it's Republican-it's Socialisticl-it's good for one-it's good for all-and best of all it's FREEl . . . It's a sure-fire-never-miss-positively-guaranteed-to-cure-all, sugarcoated bill ... ABsolutely GUARANTEED to attract, to charm and to please the young and old alikel ... IF you're a farmer, here's free housing . . . IF you're a laborer here's one HUNDRED PERCENT financing, THREE PERCENT MONEY for FORTY YEARS! Here's yield insurance! ... Here's EVERYTHING for private enterprise . . builders, brokers, bankers, building and loans! ... IT'S WHAT you WANT-AND MORE! . . . For city slickers Federal aid! . . AND BEST OF ALL, for public housers, WE ABSOLUTELx GUARANTEE unlimited Health, wealth and Expansionl ... A All of this, good folks, and More To Comel . . . for good measure; we throw in a soLID GOLD PLATED, permanent, all-powerful NHA! . . And all of this is free-it's Gratis!-it doesn't cost one silver dollar, two bits, one thin dime, the tenth part of a Billion, or one plugged nickel ... UNCLE SAMMY pays the Billsl So, STEP RXGHT UP folks-don't crowd-don't shove-Big Public Housing Show opens Soon-come one, come all-step right this way-HUREE, HUREE, HUREE l'4

As a matter of fact, there is a long history to the origin of this Bill and its sponsorship was certainly not attained by áccident.

On March r, I943, Senator Taft introduced for himself, Senator Wagner (Chairman of the Senate Banking and Currency Committee) and Senator Thomas of Utah (then Chairman of the Senate Committee on Education and Labor) S. Res. Ir2. This Resolution called for the establishment of a special committee to investigate the housing problem and to recommend a comprehensive program of housing action. The special committee was to consist of three members from the Senate Banking and

4Hearings before the Senale Committee on Banking and Currency on S. 1592, 79th Cong., Ist \& 2d Sess. (1945, 1946), Part II, 6I2. 
Currency Committee and three members from the Senate Committee on Education and Labor, the two committees in the Senate which, traditionally, had jurisdiction of housing legislation. ${ }^{5}$

While this Senate resolution was under consideration there was established, under the Chairmanship of the Honorable Walter F. George, senior Senator from Georgia, a Special Senate Committee on Postwar Economic Policy and Planning. When this special committee was set up, Senator Barkley, the majority leader, indicated that he did not desire to have other special committees established to inquire into various segments of postwar economic policy or planning. As a result, while S. Res. II2 was not further considered, its author, Senator Taft, was appointed Chairman of a Subcommittee on Housing and Urban Redevelopment of the Special Committee on Postwar Economic Policy and Planning. In lieu of appointing other members from the special committee, Senator George authorized Senator Taft to invite the Chairman of the Banking and Currency Committee and the Chairman of the Education and Labor Committee each to appoint three members to serve with him, so that there would be a working relationship with the two standing committees of the Senate which had jurisdiction of housing legislation. Senators Wagner (New York), Radcliffe (Maryland), and Ball (Minnesota) were appointed from the Banking and Currency Committee, and when Senator Ball retired from the Banking and Currency Committee in January of 1945, he was succeeded by Senator Buck of Delaware. Senators Chavez (New Mexico), Ellender (Louisiana), and LaFollette (Wisconsin) were appointed from the Committee on Education and Labor.

Hearings were held by this Subcommittee from June, r944, through February, 1945. Officials of Government agencies concerned with housing and representatives of innumerable national organizations interested in housing testified at these hearings. In addition, extensive studies and investigations were carried out by the Subcommittee and the members of its staff. On August I, I945, the Subcommittee filed its Report. The recommendations contained in the Report of the Subcommittee on Housing and Urban Redevelopment were directed to the following major items:

(I) The Congressional establishment of a national housing policy, its objectives, and the means to be employed in their attainment;

(2) The establishment of a permanent form of organization for the housing activities of the Federal Government, including the establishment of a comprehensive program to meet the special problems of improving the character of farm housing;

(3) The determination of methods of assistance by the Federal Government to private enterprise to enable it to serve more of the housing need; and

(4) The delineation of the extent and the manner in which the Federal Government shall aid communities in clearing their slums and in overcoming the inadequacies in their housing for families of very low income.

\footnotetext{
${ }^{5}$ Under Sections 102 and 121 of the Legislative Reorganization Act of 1946 (Public Law 60x, 79th Cong., 2d Sess., approved August 2, 1946) the Committees on Banking and Currency of the House and Senate will have jurisdiction of housing legislation.
} 
In August, I945, Senators Wagner and Ellender introduced the initial bill (S. r342) to carry out the recommendations of the Senate Subcommittee. At the time of the introduction of this bill, Senator Taft indicated that, while it carried out some parts of the recommendations of the Senate Subcommittee, he did not feel that it carried out all of them. However, he stated that he would be willing to work directly with Senators Wagner and Ellender during the Congressional recess in order that together they might develop a comprehensive bill to deal with the housing situation more closely along the lines of the reçommendations of the Senate Subcommittee. During the 1945 Congressional recess these Senators redrafted and perfected the initial bill. Necessarily, this meant a reconciliation of methods and details in sincere and constructive effort to attain the desired objective.

It is interesting to note that there have been few, if any, legislative proposals introduced in the Congress to which there has been devoted such continuous and painstaking consideration of even the most detailed provisions. As a matter of fact, this led Senator Wagner, who has served more than 20 years in the Senate, to say at the time of its introduction, "I can honestly say that almost no legislation within my memory has received such careful and continuous study, prior to its introduction, by a group of Senators who may be called fairly representative."

From November 27, 1945, until January 27, 1946, the Senate Banking and Currency Committee held full hearings on the bill. Following the hearings the Committee held extensive executive sessions during which they considered the bill line by line. The bill was unanimously reported by the Banking and Currency Committee to the Senate on April 8, debated, and passed by the Senate without a dissenting vote. The House Committee on Banking and Currency did not complete its hearings on the bill prior to adjournment sine die on August 2, 1946.

Quite apart from the provisions of its several titles, the Wagner-Ellender-Taft Bill would make an extremely important contribution to housing legislation in terms of a clear declaration by the Congress of a national housing objective and policy. Over the past decade and a half, the Congress has established various housing agencies to deal with particular phases of the housing problem. Quite generally, these agencies were created to deal with a specific segment of the housing problem which was currently pressing for solution. These facts were adverted to in the report of the Senate Subcommittee where it is stated:

"Thus, in order that private home mortgage institutions might more effectively meet the needs for home mortgage credit, the Home Loan Bank System was established. In the face of a general collapse of the mortgage credit structure, the Home Owner's Loan Corporation was established. In order to extend the field of mortgage credit and establish a new system of mortgage insurance, advocates of private housing secured the adoption of the National Housing Act, creating the Federal Housing Administration. In order to provide activity in the construction industry and to assist city dwellers of low income, the Public Works Administration, after experimentation with loans to private limited dividend companies, undertook the construction of public housing. Later, the interest in public housing led to the passage of the law setting up the United States Housing Author- 
ity. In each case, the need of the particular step was evident, but relation of each step to the whole was not clearly developed."

Prior to the Wagner-Ellender-Taft Bill the Congress never had the opportunity to evaluate the varied housing functions of the Government as a complete picture; it never had the opportunity to establish a national housing objective and the specific policies to be followed in attaining that objective. In this area, therefore, the Wagner-Ellender-Taft Bill makes a most significant contribution to housing legislation. It declares the national housing objective to be the "production of residential construction and related community development sufficient to remedy the serious cumulative housing shortage, to eliminate slums and blighted areas, to realize as soon as feasible the goal of a decent home and a suitable living environment for every American family." It then declares the specific policies to be followed in the attainment of this objective to be:

(I) Private enterprise shall be encouraged to serve as large a part of the total need as it can;

(2) Governmental assistance shall be utilized where feasible to enable private enterprise to serve more of the total need;

(3) Governmental aid to clear slums and provide adequate housing for groups with incomes so low that they cannot otherwise be served shall be extended only to those localities which estimate their own needs and demonstrate that these needs cannot fully be met through reliance solely upon private enterprise and without such aid; and

(4) The main housing functions of the Government shall be consolidated into a single national housing agency in order to achieve unified and coordinated activity in the execution of the declared policies.

Viewed in the light of these declared policies the Wagner-Ellender-Taft Bill has a clarity of thought and continuity of purpose seldom found in such comprehensive legislation. It is declared, first, that private enterprise shall be encouraged to serve as large a part of the total need as it can. Title II provides aids for technical research and market analysis "to enable private enterprise and localities to meet more of the need for housing and related community developments through their own efforts." Title III, through various amendments, perfects and increases the existing Government aids extended to privately financed housing through Federal Savings and Loan Association operations, Federal Home Loan Bank operations, Federal Savings and Loan Insurance Corporation operations, and Federal Housing Administration operations.

In pursuance of the second policy to be followed in the attainment of the declared national housing objective, Titles IV, V, and VI provide additional Government assistance to enable private enterprise to serve more of the total need. Title IV supplements the existing systems of mortgage insurance under the National Housing Act with special systems of mortgage insurance for families of lower income who require more favorable terms than those existing systems offer. This Title contains 
the plan for making available 95 per centum FHA insured 32-year mortgage loans, with interest at not more than 4 per centum per annum, for moderately priced homes. It also contains the provisions which would make available 95 per centum FHA insured 40-year mortgage loans, with interest at not to exceed $3 \frac{1}{2}$ per centum per annum, for housing projects undertaken by cooperatives, non-profit mutual ownership housing corporations, and educational institutions, if, in the latter case, they are undertaken primarily for the purpose of providing adequate housing accommodations for student veterans.

Title V contains the so-called "yield insurance plan" which, in essence, is an extension of the tested FHA mortgage insurance system applied to direct investments in rental housing for families of moderate income. While the plans contained in Titles IV and $\mathrm{V}$ are combined with incentives to cost reductions, the financial device alone would make possible important reductions in the monthly costs of rental housing. For example, it has been conservatively estimated that the yield insurance plan would make possible reductions of up to 20 per centum in the monthly rental charges. Thus, a rental apartment which, under the customary method of financing, could be rented at $\$ 50$ a month might be rented at about $\$ 40$ per month when financed under the yield insurance plan.

Title VI is also designed to assist private enterprise to serve more of the total need by extending aid to localities for the acquisition of land in slums and blighted areas for clearance and preparation for redevelopment in accordance with the most appropriate re-use of the land as determined by the governing body of the locality. This Title is designed to make it possible for private enterprise to participate extensively in the redevelopment of slums and blighted areas.

Title VII would provide for the perfection and resumption of the program of aid to the localities for low-rent public housing for families with incomes so low that they cannot otherwise be served. Up to I25,000 units of public low-rent housing a year for 4 years is authorized by the bill-a total of 500,000 units over the 4-year period. Consistent with the declaration of the policies to be followed, this Title requires that no aid for any such public low-rent housing shall be extended to any community unless (I) it submits an analysis of its local housing market demonstrating that there is a need for such low-rent housing which cannot be met by private enterprise; (2) it demonstrates that a gap of at least 20 per centum has been left between the upper rental limits for admission to the proposed public housing and the lowest rents at which private enterprise is providing-through new construction and existing housing-a substantial supply of good housing; and (3) the governing body of the locality approves the provision of such low-rent housing.

Title VIII provides a comprehensive program of rural housing through farm housing assistance by the Secretary of Agriculture and an extension of the urban low-rent housing program so that similar assistance will be available for low-rent housing for farm families of low income.

Title IX provides for the disposition of permanent war housing with preference 
to veterans; Title $X$ próvides for a periodic inventory of housing needs and programs to be made to the Congress so that it may evaluate the progress being made toward the attainment of the declared national housing objective and the adherence to the policies which the Congress required to be followed in attaining that objective; and Title I consolidates the main urban housing functions of the Government into a single national housing agency.

Some criticism has been leveled at the Wagner-Ellender-Tät Bill on the ground that it would be inflationary because it would liberalize credit in a period when there is ample credit available. However, such criticism completely loses sight of the main objective of the Bill which is to make it possible for private housing enterprise to build and market housing for the largest segment of the housing marketthe families of moderate income who, without the aids provided by the Bill, cannot afford to buy or rent new housing. The object of these financing plans is not to make home financing easier through liberalization of credit terms, but to make it cheaper because cheaper financing is one of the elements which enables a family of lower income to live in that kind of a house. For example, a $\$ 5,000$, 25-year, 4 $1 \frac{1}{2}$ per centum mortgage calls for financing charges of about $\$ 334$ a year, or $\$ 28$ a month. With a 32 -year, 4 per centum mortgage the financing charges would be about $\$ 277$ a year, or $\$ 23$ a month. This device, therefore, results in lowering monthly financing charges in about the same proportions as would result from a reduction in the construction of the house of about $\$ x, 000$, or 20 per centum.

The main objective of the Bill is to create a large, steady demand for new house production where no effective demand now exists. The segment of the housing market represented by middle income families is the mass market. In the aggregate, it is a highly stable market because, being in the middle, it is less affected by the ups and downs of our economy. In the main, the cost of the housing which has been produced by private enterprise has been beyond the means of the great bulk of our middle income families. Viewed realistically, there is no way in which we can reasonably expect to attain a sustained high annual volume of house production unless there is provided the means to enable private housing enterprise to produce housing within the financial means of these middle income families.

Many of the provisions of the Wagner-Ellender-Taft Bill are directed to this central point. The technical research provisions of Title II are directed to the development of new and improved techniques, materials and methods to stimulate increased production of housing and to permit progressive reductions in housing costs. Clearly a reduction in the capital cost of a house is one of the methods by which more housing can be produced within the means of middle income families. The plans contained in Titles IV and V represent financial devices through which the monthly costs of buying or renting new housing can be reduced so that more housing can be produced for middle income families who otherwise could not afford to obtain it. Clearly the reduction of monthly financing charges required to buy or rent housing is one of the methods by which more housing can be produced within the means of middle income families. 
The provisions of the Wagner-Ellender-Taft Bill with respect to Federal aid for the acquisition of slums in blighted areas and their clearance preparatory to redevelopment also bear on this central point. The costs of assembling large tracts of land required for the redevelopment of blighted urban areas generally are extremely high. If a slum or blighted area is to be redeveloped primarily for dwelling use these land costs directly affect the kind and the amount of the housing which can be produced with a fair return on the required capital investment. To bring in sufficient revenues to provide for operating expenses, debt service, and a return on the capital investment it has therefore been necessary to construct multi-storied buildings providing a large number of dwelling units at relatively high rents.

Prior to the end of the war, the Chicago Plan Commission had developed tentative plans for three projects under the Illinois Neighborhood Redevelopment Corporation Law with rents ranging up to $\$ 68$ per month. There was information to the effect that the initial plans for the Stuyvesant Town Project, which was to be developed after the war under the New York Redevelopment Companies Law, contemplated housing accommodations with rents up to $\$ 70$ per month. These estimates were made sometime ago and would probably be considerably higher on the basis of the present market. It should also be borne in mind that the value of partial tax exemption charges granted under the New York Redevelopment Companies Law represents a very substantial amount which does not have to be capitalized from rents.

It seems clear, therefore, that the redevelopment of our urban slums and blighted areas for dwelling use, even if partial tax exemption of the redeveloped properties is granted under the State law, will require such high rents that the market for such housing will necessarily be confined to a relatively small proportion of the population. In turn, this means that the extent to which slums and blighted urban areas may be redeveloped for dwelling use by private enterprise through this type of State legislation is restricted in scope because the market for dwellings at such rents is relatively small. It also means that many of the families who now live in slums and blighted areas, and whose freedom of choice as to where they shall live is strictly limited by their rent paying ability, cannot be rehoused in these areas when redeveloped and must find housing elsewhere in the community at rents within the limits of their ability to pay.

It will add nothing to the permanent assets of any municipality, either in terms of its future development, its finances, or its means of serving the needs of its citizens, to create additional blighted areas in the process of redeveloping those which already exist.

Here again the provisions of Title VI of the Wagner-Ellender-Taft Bill are directed toward lowering the rents or sales prices which must be charged for the housing accommodations provided in the course of redeveloping for dwelling use the land in slums and blighted areas. In essence, Title VI would make Federal financial assistance available to the local community on a 2-to-r matching basis to 
write off the excess costs of the acquisition of land in slums and blighted areas to the point where, if, for example, it is redeveloped for dwelling use, its cost to the redeveloper would be such that the rents or sales prices for the dwellings would be within the financial reach of the housing market to be served. By thus making it possible to lower the rents and sales prices at which good housing could be provided in these redeveloped areas, it would make possible much greater participation by private housing enterprise in the redevelopment of these areas than otherwise would be possible.

In the main, it is fair to say that the real source of the opposition to the WagnerEllender-Taft Bill comes from the fact that it does provide some low-rent public housing for those families at the base of the family income pyramid.

There is simply no basis either in past experience or in present facts to justify our proceeding on the basis that the rate at which the welfare of the Nation requires our low income families to be rehoused can possibly take place through the ordinary operations of private housing enterprise and finance. There is no honest escape from the fact that some public low-rent housing is needed.

Everyone is in favor of providing an adequate volume of good housing for low income families now living in slums and blighted areas. It is at just about this point, however, that this unanimity of opinion ends and disagreement begins. While there is agreement upon the objective; there is disagreement only as to the means necessary to accomplish the objective.

Many of the groups opposing the Wagner-Ellender-Taft Bill because it provides some public housing seriously contend that it is not necessary-that the means best calculated and most desirable to remedy the unsatisfactory conditions under which a very large number of our families are housed is not through subsidized public housing, but by constructive measures to improve the earning power of this group. This ignores some very tangible truths.

It has been the firm and long-established policy of the Government of the United States to make possible equal opportunity for every individual to earn rewards for his labor according to his ability, and to improve, progressively, the standards and conditions under which its citizens live and work. Adherence to this policy has established, for the great majority of our citizens, standards of living and conditions of work unequalled elsewhere in the world. But this policy of the Government, and the private enterprise system which itself is preserved by that policy, both operate on the reality that, while men were created free and have an equal right to opportunity, they do not have an equal right to the rewards of opportunity excepting as they earn them-each according to his own ability. Thus, there is and always will be in this policy, and in the private enterprise system, this fundamental inequalitylabor cannot be priced at more than the product thereof is worth even though the price at which it is bought may not permit the seller to earn a decent living for himself and his family.

This policy and this system work well for a majority of our citizens; but, for a 
substantial minority, they do not. Even when most of our labor force is employed, large numbers of workers are frequently employed at wages which are not sufficient to enable their families, by their own means, to obtain a minimum of the essentials -including decent housing. Through constructive measures to improve the earning power of this group, the Government can and has reduced the number of families in this group. These measures include laws, both Federal and State, relating to educational policies and aids, minimum wages, hours of work, collective bargaining, health and safety, unemployment compensation, and disability and old age assistance. But the inequality in terms of rewards commensurate with ability, which is fundamental to our governmental policy and to the private enterprise system, cannot be entirely removed by such measures-unless we remove the private enterprise system too. Certainly there is agreement that we do not want to do that.

Necessarily, therefore, there will continue to be a sizable number of our citizens who, for one reason or another, will not earn sufficient income to enable them to live under conditions which the great majority of our people, and the Government which is representative of them, consider minimum. Unless we are willing to accept a governmental policy and an economic system which condemns a substantial minority of our citizens to live under conditions less than minimum, then the majority, for whom this policy and system work well, have the obligation to assure that the low income group will have the minimum essentials of life-including decent, safe, and sanitary housing. This is the "quid pro quo" for the retention of our established governmental policy and the private enterprise system.

It is because of these considerations that the principle that the Government should make financial assistance available to local communities to provide minimum decent, safe and sanitary housing for families of very low income has found wide acceptance. Of this principle Senator Taft has said:

"It is the best method which I have been able to discover. It is somewhat different from the method pursued in other fields, but it is the best method which I have been able to discover, after two years or more of hearings, by which we can hope to provide a reasonably decent standard of housing for a large number of people who are unable, whether through their own fault, through the fault of the system, or through misfortune, to obtain with their own means a reasonably decent standard of housing accommodations."

On the whole, the Wagner-Ellender-Taft Bill steers a middle course. It does not go too far but, at the same time, the Senate has not been afraid to go far enough to provide the means to deal adequately with established housing needs. There is nothing in it which is entirely experimental in character or entirely untested by experience. Most of the changes made by Title II in the operations of the Federal Home Loan Bank Administration and the Federal Housing Administration have grown out of the operating experience of those agencies and have long been advocated by the private home financing institutions and private home builders participating in the programs now carried out through those agencies.

- 92 Cong. Rec., April 11, 1946, at 3582. 
Title IV is essentially an extension of existing systems of FHA mortgage insurance to meet the special needs of families of moderate income who require more favorable financing terms than the present FHA systems offer. It is a realistic effort, based on some I2 years of operating experience, to further the original purpose of the FHA to encourage pioneering in the development of a wider market for housing by improved loan facilities and to make more attractive the investment of private funds in lower-cost housing.

As already pointed out, the yield insurance plan contained in Title $\mathrm{V}$ is, by and large, the FHA mortgage insurance system modified to meet the needs of direct investment in rental housing as compared with indirect investment in such housing through mortgage financing. In an article in the October issue of the Architectural Forum, Mr. Thomas Holden, President of the F. W. Dodge Corporation, indicates strong support for the yield insurance Title of the Wagner-Ellender-Taft Bill.

Title VII is largely a perfection and resumption of the system of aid to localities for low-rent public housing in a volume which, in the judgment both of the Taft Subcommittee and the Senate Banking and Currency Committee, admittedly is much less than the amount required to meet known needs.

Title VI is the first constructive effort to make possible sufficient progress in the rebuilding of slum and blighted urban areas (which thus far has, in effect, been limited to the size of the public low-rent housing program) by making possible their reuse for a variety of purposes, including private enterprise housing for middle and low income families, as well as for public housing.

In this connection it should again be emphasized that the desirability of Federal assistance to make possible the redevelopment of slums and blighted urban areas seems no longer to be in question; the question now relates to methods rather than to the objective. The Congress has already enacted the District of Columbia Redevelopment Act of 1945, which was sponsored by Senator McCarran of Nevada, Mr. Justice Burton, the junior Senator from Ohio when this bill was introduced in the Congress, and Senator Capper of Kansas. By this Act the Congress undertook to make $\$ 20,000,000$ available to the District of Columbia for the acquisition and clearance of land in slums and blighted areas and to write off the excess cost of such land over its re-use value on a 50-50 matching basis with the locality.

On February 14, 1946, Congressman Baldwin of Maryland introduced the Slum Clearance Bill of 1946 (H. R. 5482), authorizing the appropriation of a billion dollars to the Reconstruction Finance Corporation for loans and grants to public bodies to acquire and clear slums and blighted areas for redevelopment. Here again the Federal Government would write off the excess land costs with the locality on a 50-50 matching basis.

Also, on April r8, 1946, Congressman Wolcott of Michigan, introduced H. R. 6205, which, among other things, would authorize a similar loan and capital grant program, aggregating one billion dollars, to be administered by the Reconstruction Finance Corporation. Under this bill also, the Federal Government would write off the excess land costs with the locality on a 50-50 matching basis. 
The Veterans' Emergency Housing Program announced in February of this year called for the construction of $1,200,000$ dwellings to be started in 1946 and $1,500,000$ to be started in 1947. At present, the indications are that something close to $\mathrm{r}, 000,000$ dwellings of all types, and including about 700,000 to 750,000 new permanent dwellings, will be started in 1946. It now appears that, in one year under the Veterans' Emergency Housing Program there will have been achieved an increase in the rate of house production comparable to that which after World War I took several years to attain. In terms of volume, it must be admitted that this is a remarkable achievement-especially in view of the critical shortage of various types of building materials which existed after V-J Day.

In terms of the distribution of the housing that is thus being produced, however, there are two major deficiencies. Not enough rental housing is being produced and veterans need a very substantial amount of rental housing. The' lack of the WagnerEllender-Taft Bill, which was relied upon to make possible the production of an adequate volume of rental housing, is showing up in this area. Also, much of the housing that is being produced is priced too high for veterans. Here again, the lack of the W.igner-Ellender-Taft Bill is showing up. The Senate Committee on Banking and Currency was not unaware of this difficulty, as indicated by its statement that

". . . it is necessary to point out precisely and unequivocally how the bill now being reported is equally a part of the veterans' emergency housing program and equally indispensable to its achievement....

'The veterants' emergency housing program calls for 2,700,000 houses to be started during 1946 and 1947 . It is intended that these houses be for veterans and their families. Measures such as premium payments and allocations and priorities-contained in $H$. $R$. $476 \mathrm{I}$ as reported by the committee-are essential to getting the materials with which to build these houses. But when these houses are built, and even to provide an effective and sound demand for them when they are built, they must be priced for sale or rent within the financial means of the majority of veterans and their families. Otherwise, it is obvious that these houses will go mainly to nonveterans' families of higher income. This would largely defeat the purposes of the veterans' emergency housing program."7

' Calendar No. 1I47, SEN. Rep. No. Ir3I, 79th Cong., 2d Sess. (1946) p. 3.

It must be recognized that the peak of the housing shortage probably has not yet been reached. While we have passed the peak of our military demobilization, the peak of newly formed families, resulting especially from the high marriage rate among veterans, may not be reached until some time this winter or next spring. Moreover, the shortage of housing is so great that even if the original goals of the Veterans' Emergency Housing Program of $x, 200,000$ starts in 1946 and $x, 500,000$ starts in 1947 are attained, only the sharp edge will be taken off the shortage. The pressures for the production of rental housing in a volume adequate to meet the needs of veterans, and to get more of the housing that is produced available at prices more in line with what veterans can pay, will be extreme. The potentials therefore clearly exist for much more extreme legislative proposals than the Wagner-EllenderTaft Bill. 